\title{
EL ETERNO RETORNO DE LO MISMO, «EL PENSAMIENTO FUNDAMENTAL DE ZARATUSTRA»
}

The eternal recurrence, «the basic conception of Zarathustra»

\author{
Scarlett Marton
}

Universidad de Sao Paulo, Brasil

Resumen: En Ecce Homo, Nietzsche establece que la concepción básica de Así habló Zaratustra consiste en «la idea del eterno retorno, la más alta fórmula de la afirmación que puede ser alcanzada posiblemente». Tomando como punto de partida el análisis de las diferentes partes de este libro, trataremos en primer lugar de definir el lugar del pensamiento del eterno retorno. Al establecer la relación de este pensamiento con la noción de superhombre, el concepto de voluntad de poder, el proyecto de la transvaloración de los valores y la idea del amor fati, tratamos de examinar el modo en que Nietzsche lo concibe en Así habló Zaratustra. A continuación, tratamos de evaluar en qué medida el pensamiento del eterno retorno en la más alta aceptación del mundo tal como es.

Palabras clave: Zaratustra - eterno retorno - superhombre - voluntad de poder - transvaloración de los valores - amor fati

ABSTRACT: In Ecce homo, Nietzsche states that the basic conception of Thus spoke Zarathustra consists in «the idea of eternal recurrence, the highest formula of affirmation that can possibly be attained». Taking as a point of departure the analysis of the different parts of this book, first of all we intend to define the place of the thought of eternal recurrence. Establishing the relation of this thought with the notion of overman, the concept of will to power, the project of transvaluation of the values, and the idea of amor fati, we plan to examine the way Nietzsche conceives it in Thus spoke Zarathustra. Then we aim at evaluating to which extent the thought of eternal recurrence consists in the highest acceptation of the world as it is.

Keywords: Zarathustra - eternal recurrence - overman - will to power - transvaluation of the values - amor fati

En Ecce Homo, a la vez que abrda la cuestión de la comprensión de sus escritos, Nietzsche se ocupa de sus libros publicados. Reconstruye por tanto la génesis de Así habló Zaratustra, examinando de cerca las circunstancias que dieron origen al personaje central que él confía presentar a sus lectores, así como al mensaje que él espera traerles. Proponiéndose contar la historia de este libro, afirma de entrada: «La concepción fundamental de la obra, el pensamiento del eterno retorno, esa fórmula suprema de afirmación a que se puede llegar en absoluto, — es de agosto del año 1881: se encuentra anotado en una hoja a cuyo final está escrito: 'A 6.000 pies más allá del hombre y del tiempo’» ${ }^{1}$.

1. Ecce Homo, «Así habló Zaratustra», $\mathbb{1}$, KSA VI 335. 
Preguntarse por las razones que han llevado a Nietzsche a considerar el pensamiento del eterno retorno como él lo hace es lo que guiará nuestra investigación. Tomando como punto de partida el análisis de las diferentes partes de Así habló Zaratustra, tenemos la intención de definir el lugar que allí ocupa el pensamiento del eterno retorno. Poniéndolo en relación con la noción de superhombre, el concepto de voluntad de poder, el proyecto de transvaloración de los valores y la idea de amor fati, esperamos posteriormente dilucidar este pensamiento tal como ha sido formulado en este libro. Perseguimos finalmente el objetivo de evaluar en qué medida este pensamiento consiste en la más elevada aquiescencia del mundo tal como es.

Así habló Zaratustra comienza con el anuncio de la transformación que el personaje central acaba de sufrir. Durante una decena de años ha vivido en la soledad de su caverna y de su montaña; "pero al fin su corazón se transformó»². Anunciado en las primeras líneas del prólogo y reiterado en la sección siguiente, la transformación de Zaratustra finalmente se hace clara. Su causa radica en el conocimiento de la muerte de Dios ${ }^{3}$. El dualismo de los mundos, que constituye un rasgo esencial de nuestra cultura, ha sido inventado por el pensamiento metafísico y por la religión cristiana. Devaluando este mundo en nombre de otro mundo, que sería esencial, inmutable y eterno, la cultura socrática-judeo-cristiana se convierte en nihilista. Es por tanto la muerte de Dios la que hará posible a Zaratustra hacer la travesía del nihilismo. Si los valores han encontrado siempre su legitimidad en el mundo suprasensible, se trata ahora de eliminar el terreno a partir del cual han sido engendrados, con objeto de crear otros valores. «Humanos, demasiado humanos», los valores establecidos han surgido en un momento dado en un lugar determinado ${ }^{4}$. Y no importa ni en qué momento ni en qué lugar, nuevos valores podrán ser creados. Es la muerte de Dios lo que permitirá a Nietzsche abordar el proyecto de transvaloración de todos los valores.

En las primeras líneas de Así habló Zaratustra, cuando deja su caverna, el personaje central se dirige al sol. Después de haber iluminado la tierra, el astro rey desciende todos los días sobre el horizonte; después de haber estado hastiado de su sabiduría, Zaratustra debe descender hacia el valle para frecuentar de nuevo a los hombres. Habiendo evocado en su bajada la muerte de Dios, llega entonces a la ciudad; se dirige al pueblo reunido en la plaza del mercado diciéndole: «Yo os enseño el superhombre. El hombre es algo que debe ser superado» ${ }^{5}$. En estas circunstancias exhorta a sus oyentes a permanecer fieles a la Tierra. Si antes el más

2. Así habló Zaratustra I, «Prólogo», $\mathbb{1} 1$, KSA IV 11.

3. Véase La gaya ciencia $\$ 125$, KSA III 480s., donde este tema aparece por primera vez en la obra de Nietzsche. Después de la elaboración de Así habló Zaratustra, reaparecerá en el primer parágrafo del quinto libro de La gaya ciencia $(\$ 343)$.

4. En Más allá del bien y del mal y en La genealogía de la moral, Nietzsche retomará estas ideas presentes en Así habló Zaratustra. En lo que se refiere a la idea de que los valores son «humanos, demasiado humanos», cf. La genealogía de la moral, «Prefacio», \$ 6, KSA V 253.

5. Así habló Zaratustra I, «Prólogo», \$3, KSA IV 14. 
grande delito era el cometido contra Dios, ahora es un sacrilegio aún más grande cometer un delito contra la Tierra; si en el pasado el alma despreciaba al cuerpo, ahora es el cuerpo el que deja claro la miseria del alma; si anteriormente era el hombre, concebido como una criatura en relación con el Creador, quien daba un sentido a lo que le rodeaba, ahora no es más que un puente hacia el superhombre. Por tanto, Zaratustra aparece en la primera parte del libro como el anunciador del superhombre. De hecho, en la cuarta sección del prólogo se presenta él mismo de esta manera: «Yo amo a todos aquellos que son como gotas pesadas que caen una a una de la oscura nube suspendida sobre el hombre: ellos anuncian que el rayo viene, y perecen como anunciadores. Mirad, yo soy un anunciador del rayo y una pesada gota que cae de la nube: mas ese rayo se llama superhombre» ${ }^{6}$.

En varios pasajes de Así habló Zaratustra, Nietzsche se centrará en aclarar cómo concibe esta noción. En la sección titulada «De los despreciadores del cuerpo», dirigiéndose a los que menosprecian el cuerpo, Zaratustra comienza diciendo que no deben cambiar lo que han aprendido o enseñado sino sencillamente callarse. El objetivo que persigue en esta sección consiste en atacar la dicotomía entre el cuerpo y el alma y, de este modo, combatir la idea de un «yo», de un sujeto que permanece idéntico en su individualidad. Como concepciones metafísicoreligiosas, el alma y el yo, pero también el espíritu, la razón y la conciencia, se incluyen en el mismo registro teórico. En este sentido, todo tipo de interioridad se convierte en un instrumento y un juguete del cuerpo. Aplicando el procedimiento genealógico, Zaratustra remite por eso los valores a las valoraciones que los han engendrado: el desprecio que sus adversarios tienen del cuerpo se basa en la estima que tienen por el alma; a continuación, evalúa las valoraciones: en los que desprecian el cuerpo es el sí mismo (Selbst) quien quiere perecer, es el cuerpo mismo el que quiere desaparecer. Efectuado su diagnóstico, Zaratustra reafirma su distancia contra sus adversarios: «iYo no voy por vuestro camino, despreciadores del cuerpo! iVosotros no sois para mí puentes hacia el superhombre!» 7 .

Retomando una idea bastante frecuente en los escritos de Nietzsche, la de la oposición entre la política y la cultura, Zaratustra dirige severas críticas al Estado en la sección titulada «Del nuevo ídolo». Sostiene en este caso la idea de que «el más frío de todos los monstruos fríos» no hace más que producir la nivelación de todos los individuos, suprimiendo sus singularidades y sus diferencias. El Estado privaría a todos los sometidos a él de la capacidad creadora y del espíritu crítico. Pero para las grandes almas, que pueden aún tener una vida libre, Zaratustra anuncia lo que deberá suceder: «Allí donde el Estado acaba, — mirad allí, ihermanos míos! ¿No veis el arco iris y los puentes del superhombre?» ${ }^{\circledR}$.

Una vez más Zaratustra se presenta como el anunciador del superhombre en la sección titulada «De las mil metas y de la única meta». Mostrando que los valores son «humanos, demasiado humanos», les atribuye un origen y una historia. De este modo, destruye el terreno a partir del cual habían sido establecidos hasta

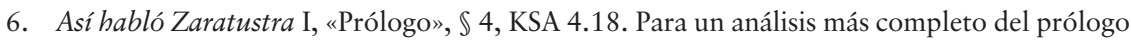
de Así habló Zaratustra, remitimos a nuestro estudio «Nietzsche et sa recherche d'interlocuteurs: une analyse du prologue d'Ainsi parlait Zarathoustra», en C. Denat y P. Wotling (coords.), Nietzsche. Un art nouveau du discours, Reims: Épure, 2013, pp. 81-101.

7. Así habló Zaratustra I, «De los despreciadores del cuerpo», KSA IV 41.

8. Así habló Zaratustra I, «Del nuevo ídolo», KSA IV 64. 
ahora. Dirigiendo la lucha contra el dualismo de los mundos, puede desmoronar la interpretación impuesta por el pensamiento metafísico y por la religión cristiana. Sin embargo, Zaratustra es plenamente consciente de que el cambio de valores exige previamente el cambio de creadores. Entendiendo la transvaloración de todos los valores como una obra análoga a la de los legisladores, piensa que, para ello, será necesario concebir al hombre de otra manera. Así pues, solo con el superhombre será posible transvalorar todos los valores. Anunciando lo que debe ocurrir, Zaratustra concluye su discurso diciendo: «Mil metas ha habido hasta ahora, pues mil pueblos ha habido. Solo falta la cadena que ate las mil cervices, falta la única meta. Todavía no tiene la humanidad meta alguna. Mas decidme, hermanos: si a la humanidad le falta todavía la meta, ¿no falta todavía también - ella misma?»?.

En «De la virtud que hace regalos», la última sección de la primera parte del libro, al despedirse de sus discípulos recibe de sus manos un bastón cuyo puño de oro representa una serpiente enroscándose alrededor del sol. Dado que el oro es la imagen de la virtud suprema, este regalo señala la actitud que el mismo Zaratustra adopta; este regalo deja claro que él se presenta como donante de su propia sabiduría. En este sentido, el prólogo y los discursos que siguen, tomados en su conjunto, muestran un movimiento circular: se inician y finalizan con la idea de exceso. Además, el regalo que Zaratustra recibe muestra igualmente la tarea que él asume. Se presenta como médico de las enfermedades de este mundo; su bastón evoca el cetro de Esculapio. Desde esta perspectiva, el prólogo y los discursos que siguen, tomados en su conjunto, exhiben también un movimiento circular: empiezan y acaban con la lucha contra el nihilismo. Si la muerte de Dios posibilita a Zaratustra hacer la travesía del nihilismo, le permite también considerar el proyecto de transvaloración de todos los valores. Exhortando a sus discípulos a permanecer fieles a la Tierra, Zaratustra los incita a contribuir a que hagan posible el superhombre: "Muertos están todos los dioses: ahora queremos que viva el superhombre" — iSea esta alguna vez, en el grande mediodía, nuestra última voluntad!» ${ }^{10}$.

Los elementos reunidos hasta ahora nos permiten aclarar la noción de superhombre tal y como ha sido formulada en la primera parte del libro ${ }^{11}$. El superhombre se sitúa más allá de viejas dicotomías del pensamiento metafísico. No se identifica con el sujeto, concebido como un sustrato que produce efectos, realiza actividades y posee unas propiedades; no se confunde tampoco con el yo, entendido como una totalidad independiente, completa, idéntica a sí misma, permanente y unitaria. El superhombre no se hallará entre los individuos superfluos, demasiado numerosos; no vendrá a promover un cambio político. Estrechamente vinculado al proyecto de transvaloración de los valores, la no-

9. Así habló Zaratustra I, «De las mil metas y de la única meta», KSA IV 76.

10. Así habló Zaratustra I, «De la virtud que hace regalos», $\mathbb{3}$, KSA IV 102. Cf. igualmente «De la virtud que hace regalos», $\mathbb{S}$, KSA IV 100s., donde Zaratustra dirige una exhortación similar a sus discípulos: «Vosotros los solitarios de hoy, vosotros los apartados, un día debéis ser un pueblo; de vosotros, que os habéis elegido a vosotros mismos, debe surgir un día un pueblo elegido - y de él, el superhombre».

11. Nietzsche alude a la noción de superhombre también en Así habló Zaratustra I, «Del pálido delincuente», KSA IV 45; «Del amigo», KSA IV 72; «Del amor al prójimo», KSA IV 78; «De las mujeres viejas y jóvenes», KSA IV 85; «Del hijo y del matrimonio», KSA IV 92. 
ción de superhombre indica la necesidad de una completa inversión de la cultura occidental ${ }^{12}$.

Asimismo, estamos en condiciones de comprender mejor el proyecto de transvaloración de los valores tal como aparece en Así habló Zaratustra ${ }^{13}$. Instando al pueblo reunido en la plaza del mercado a permanecer fiel a la Tierra, el personaje central viene a indicar que al contrario de los que preconizan el pensamiento metafísico y la religión cristiana, no es el mundo transcendente el que debe ser tomado como sede de los valores. Considerando la transvaloración de todos los valores como una empresa al mismo tiempo destructora y creadora en la sección titulada «De las mil metas y de la única meta», la asocia directamente a una concepción diferente de la humanidad. Hasta ahora, es el hombre, concebido como una criatura en relación al Creador, el que ha valorado y establecido, como fruto de su valoración, unos valores que han desvalorizado la Tierra, depreciado la vida y despreciado el cuerpo. Así pues, es necesario combatir estos valores con el fin de hacer surgir otros. Como criatura y creador por sí mismo, el superhombre apreciará los valores que estarán en consonancia con la Tierra, con la vida, con el cuerpo ${ }^{14}$.

Si constatamos que en la primera parte de Así habló Zaratustra la noción de superhombre ocupa un lugar predominante, no podemos abstenernos de destacar allí también varias alusiones al pensamiento del eterno retorno. En la primera página del prólogo, están ya presentes temas principales de la última filosofía de Nietzsche. Aquí aparece repetidas veces la idea de exceso ${ }^{15}$, que constituirá un elemento fundamental del concepto de voluntad de poder; aquí surge el proyecto de la transvaloración de todos los valores ${ }^{16}$, que jugará un papel decisivo en diferentes textos; aquí se encuentra sugerida la noción de curso circular ${ }^{17}$, que resultará central en el pensamiento del eterno retorno de lo mismo.

12. En Ecce Homo, Nietzsche aporta luz sobre este término: «La palabra 'superhombre', que designa un tipo de óptima constitución, en contraste con los hombres 'modernos', con los hombres 'buenos', con los cristianos y demás nihilistas - una palabra que, en boca de Zaratustra, el aniquilador de la moral, se convierte en una palabra muy digna de reflexión, ha sido entendida casi en todas partes, con total inocencia, en el sentido de aquellos valores cuya antítesis se ha manifestado en la figura de Zaratustra, es decir, ha sido entendida como tipo 'idealista' de una especie superior de hombre, mitad 'santo', mitad 'genio'...» Ecce Homo, «Por qué escribo tan buenos libros», $\mathbb{S} 1$, KSA VI 300.

13. Para un análisis más profundo del proyecto de la transvaloración de todos los valores en la obra de Nietzsche, remitimos a nuestro estudio «Nietzsche: la obra hecha y la obra todavía por hacer»: Estudios Nietzsche 2 (2002), 181-203.

14. Cuando anuncia el superhombre al pueblo reunido en la plaza del mercado, Zaratustra proclama: «El superhombre es el sentido de la tierra. Diga vuestra voluntad: isea el superhombre el sentido de la tierra! Yo os conjuro, hermanos míos, ipermaneced fieles a la tierra y no creáis a quienes os hablan de esperanzas supraterrenales!» (Así habló Zaratustra I, «Prólogo», $\$ 3$, KSA IV 14s.).

15. En Así habló Zaratustra, «Prólogo», $\mathbb{S} 1$, KSA IV 11, la idea de exceso se hace presente en los términos «superfluo» (Überfluss), «empacho» (überdrüssig), «opulento» (überreich), «desbordar» (überfliessen).

16. En esta misma sección del prólogo de Así habló Zaratustra, KSA IV 11, este proyecto se halla presente en la aspiración de Zaratustra a «regalar y repartir [su sabiduría] hasta que los sabios entre los hombres hayan vuelto a regocijarse con su locura, y los pobres, con su riqueza».

17. La noción de curso circular se expresa en esta primera sección del Prólogo de Así habló Zaratustra (KSA IV 11), a través de la imagen del sol que se pone y que todos los días velve a salir. 
En la sección titulada «De las tres transformaciones», reaparecen temas centrales de la última filosofía de Nietzsche. Sometiéndose a lo que él considera como transcendente, obedeciendo a los valores establecidos, soportando la vida como una carga bastante pesada, el espíritu se convierte en camello ${ }^{18}$. Pero en la soledad del desierto, el camello se transforma en león. Su tarea consiste en rebelarse contra las diferentes formas de la heteronomía; luchando contra el gran dragón, que se llama «Tú debes», él le opone un «Yo quiero». Como un espíritu libre se rebela contra cualquier tipo de autoridad; porque es capaz de sentir el gran despre$\mathrm{cio}^{19}$, representa la condición de posibilidad de la transvaloración de los valores. Pero en el desierto más solitario, el león se transforma en niño. "Inocencia es el niño, y olvido, un nuevo comienzo, un juego, una rueda que se mueve por sí misma, un primer movimiento, un santo decir sí» ${ }^{20}$. La muerte de Dios y la superación del nihilismo hacen que sea innecesaria la justificación del mundo; reconocemos la inocencia del devenir ${ }^{21}$. La eliminación del virus corrosivo de la culpabilidad hace innecesaria la preservación de la memoria, que no hace más que asociar la deuda y el castigo; admitimos el olvido ${ }^{22}$. Resulta entonces posible concebir el mundo y la vida de otra manera y crear otros valores sobre bases nuevas, en pocas palabras, es posible «un nuevo comienzo». Aceptar el eterno retorno de todas las cosas, esta «rueda que se mueve por sí misma» ${ }^{23}$, esto representa «un primer movimiento». Adherirse de manera incondicional a todo lo que sucede, acoger el sufrimiento como parte integrante de la existencia, aceptar el amor fati, equivale a «un santo decir sí» ${ }^{24}$ a la vida.

18. Cf. Así habló Zaratustra III, «Del espíritu de la pesadeZ», $\$ 2$, KSA IV 243, donde podemos leer: «iPero solo el hombre es para sí mismo una carga pesada! Y esto porque lleva cargadas sobre sus hombros demasiadas cosas ajenas. Semejante al camello, se arrodilla y se deja cargar bien». Sobre la figura del camello, cf. también Genealogía de la moral, «Tratado tercero», $\mathbb{S} 8$, KSA V 353.

19. Cf. Así habló Zaratustra I, «Prólogo», $\mathbb{3}$, KSA IV 15: «¿Cuál es la máxima vivencia que vosotros podéis tener? La hora del gran desprecio». Cf. también Así habló Zaratustra I, «Prólogo", \$ 4, KSA IV 17: «Yo amo a los grandes despreciadores, pues ellos son los grandes veneradores, y flechas del anhelo hacia la otra orilla».

20. Así habló Zaratustra I, «De las tres transformaciones», KSA IV 31.

21. Cf. Así habló Zaratustra II, «Del inmaculado conocimiento», KSA IV 157: «¿Dónde hay inocencia? Allí donde hay voluntad de engendrar. Y el que quiere crear por encima de sí mismo, ese tiene para mí la voluntad más pura».

22. Cf. Así habló Zaratustra III, «El retorno a casa»,KSA IV 233, donde de vuelta a su caverna y a su montaña, Zaratustra habla con la soledad, diciéndole: «Pero allá abajo - iallá es vano todo hablar! Allá, olvidar y pasar de largo es la mejor sabiduría: esto — ilo he aprendido ahora!» Cf. también Genealogía de la moral, «Tratado primero», \$10, KSA V 273.

23. Esta imagen reaparece en la sección titulada «El convaleciente», $\mathbb{2}$, KSA IV 272, donde los animales de Zaratustra, el águila y la serpiente, le recuerdan el hecho de que él es el maestro del eterno retorno. En un momento dado ellos le dicen: «Todo va, todo vuelve; eternamente rueda la rueda del ser. Todo muere, todo vuelve a florecer, eternamente corre el año del ser».

24. Cf. Así habló Zaratustra III, «Antes de la salida del sol», KSA IV 208s., donde podemos leer: «Mas yo soy uno que bendice y que dice sí, con tal de que tú estés a mi alrededor, itú puro, luminoso! itú abismo de luz! - a todos los abismos llevo yo entonces, como una bendición, mi decir sí». Cf. también Así habló Zaratustra III, «Del gran anhelo», KSA IV 278: «Oh alma mía, te he dado el derecho de decir no como la tempestad y de decir sí como dice sí el cielo abierto». 
Resulta sorprendente observar que en la segunda parte de Así habló Zaratustra se multiplican las alusiones al pensamiento del eterno retorno, mientras que la mención del superhombre es cada vez más rara. Es cierto que, en la sección titulada «En las islas afortunadas», Zaratustra se presenta como el anunciador del superhombre. Asociando esta noción con la muerte de Dios, insta a sus discípulos a mantenerse alejado de la gran fatiga, de la fatiga que conduce a abstenerse de querer unos nuevos valores, de establecerlos y de crearlos. Y concluye su discurso diciéndoles: «La belleza del superhombre llegó hasta mí como una sombra. iAy, hermanos míos! ¿Qué me importan ya - los dioses! » ${ }^{25}$.

Hasta el momento todo va como si la segunda parte del libro no aportase nada nuevo respecto a la noción de superhombre ${ }^{26}$. Es sobre todo la vertiente crítica de la filosofía nietzscheana la que allí se expresa. Zaratustra se pone a combatir la creencia en Dios, la compasión, la religión, las virtudes cristianas, la vulgaridad, la idea de igualdad, la voluntad de verdad, el penitente del espíritu, los hombres contemporáneos, la contemplación, la erudición, la noción de imperecedero, la idea de revolución, el nihilismo, el espíritu de venganza ${ }^{27}$.

De todos modos, habría que examinar con mayor detalle la sección titulada «De la superación de sí mismo». Ahí Zaratustra alude nuevamente a la idea de que él es el anunciador del superhombre. Dirigiéndose a los más sabios de los sabios, que se dejan presionar por la voluntad de verdad, señala que con la superación de los valores que ellos han establecido surgirá la creación de nuevos valores. Ya modo de conclusión, afirma: «iY que caiga hecho pedazos todo lo que en nuestras verdades - pueda caer hecho pedazos! iHay muchas casas que construir todavía! ${ }^{28}$. Zaratustra retoma aquí una idea que ya había sido expresada en la cuarta sección del prólogo del libro, en la que él se presentaba como el anunciador del superhombre. En ese momento él identificaba a todos los que jugaban, igualmente, el papel de los predicadores y destacaba entre ellos a «quien trabaja e inventa para construirle la casa al superhombre» ${ }^{29}$.

Pero esta sección es aún más importante puesto que introduce un concepto fundamental de la última filosofía de Nietzsche. A la voluntad de verdad que anima a los más sabios de los sabios, Zaratustra viene a oponer la voluntad de poder. Hace entonces el relato de lo que la vida misma le ha encomendado: «Solo donde hay vida hay también voluntad: pero no voluntad de vida, sino, así te lo enseño yo - ivoluntad de poder! Muchas cosas tiene el viviente en más alto aprecio que

25. Así habló Zaratustra II, «En las islas afortunadas», KSA IV 112. Cf. también la sección «De los sacerdotes", KSA IV 112, donde criticando la manera de proceder de los sacerdotes hace ver que la muerte de Dios es necesaria.

26. Nietzsche se ocupa de la noción de superhombre también en Así habló Zaratustra II, «De las tarántulas», KSA IV 130; «De los poetas», KSA IV 164; «De la cordura respecto a los hombres», KSA IV 183ss.

27. Cf., respectivamente, Así habló Zaratustra II, «En las islas afortunadas», «De los compasivos», «De los sacerdotes», «De los virtuosos», «De la chusma», «De las tarántulas», «De los sabios famosos», «De los sublimes», «Del país de la cultura», «Del inmaculado conocimiento», «De los doctos», «De los poetas», «De los grandes acontecimientos», «El adivino», «De la redención».

28. Así habló Zaratustra II, «De la superación de sí mismo», KSA IV 149.

29. Así habló Zaratustra I, «Prólogo», \$4, KSA IV 17. 
la vida misma: pero en el apreciar mismo habla — ila voluntad de poder! ${ }^{30}$. Dos ideas requieren aquí nuestra atención. Por una parte, Nietzsche identifica la vida con la voluntad de poder. Marcando distancias con su antiguo maestro, rechaza la «voluntad de vivir» schopenhaueriana. A diferencia de esta idea, la noción de vida y el concepto de voluntad de poder no son principios transcendentes; la vida no se encuentra más allá de los fenómenos y la voluntad de poder no existe más allá del ser viviente. Por otra parte, Nietzsche establece una estrecha relación entre las nociones de vida y de valor, por un lado, y el concepto de voluntad de poder, por otro. Muestra que es la vida, ella misma, quien establece valores; es la voluntad de poder la que valora. De ahí que, Nietzsche dé a entender que él ya entrevé un único proceso en el ámbito socio-psicológico y en el ámbito biológico. El concepto de voluntad de poder, además de contribuir a explicar los fenómenos biológicos, constituirá un parámetro esencial en el análisis de los fenómenos psicológicos y sociales: será considerado como el criterio de valoración de los valores ${ }^{31}$.

Fundamentalmente, es en la sección «De las mil metas y de la única meta» de la primera parte de Así habló Zaratustra donde Nietzsche introduce en u obra publicada el concepto de voluntad de poder. Considerando que los valores son necesarios para la vida de los pueblos y que difieren de un pueblo a otro, Zaratustra afirma: «Una tabla de valores está suspendida sobre cada pueblo. Mira, es la tabla de sus superaciones; mira, es la voz de su voluntad de poder». A este concepto, Nietzsche vuelve en la segunda parte del libro, en primer lugar en la sección «De la superación de sí mismo» y después en la titulada «De la redención». Señalando que la voluntad de poder lleva a los hombres a abolir la culpabilidad y el castigo y a querer lo que ya sucedió, Zaratustra afirma: «Algo superior a toda reconciliación tiene que querer la voluntad que es voluntad de poder - : sin embargo, ¿̇cómo le ocurre esto? Quién le ha enseñado incluso el querer hacia atrás?»32. En los dos pasajes, Nietzsche inscribe el concepto de voluntad de poder en el marco de sus reflexiones de orden psicológico y social, considerándolo como la posibilidad de un pueblo de superarse o de un individuo de redimir su existencia. En el primer caso, entiende por la expresión Wille zur Macht la búsqueda de la preeminencia; en el último, la toma como un elemento del pensamiento del eterno retorno ${ }^{33}$.

Estamos, pues, en condiciones de afirmar que en la sección «De las mil metas y de la única meta» de la primera parte del libro lo mismo que en las secciones «De la superación de sí mismo»y «De la redención» de la segunda parte, el con-

30. Así habló Zaratustra II, «De la superación de sí mismo», KSA IV 149.

31. Para una exposición más detallada de esta problemática, reenviamos a nuestro estudio «À la recherche d'un critère d'évalution des évaluations. Les notions de vie et de valeur chez Nietzsche», en C. Dénat y P. Wotling (coords.), Les hétérodoxies de Nietzsche. Lectures du Crépuscule des idoles, Reims: Épure, 2014, pp. 321-342.

32. Respectivamente, Así habló Zaratustra II, «De las mil metas y de la única meta», KSA IV 74, y «De la redención», KSA IV 181.

33. Será sobre todo en el ámbito de sus preocupaciones cosmológicas donde, gracias a su teoría de las fuerzas, Nietzsche establezca una estrecha relación entre el concepto de voluntad de poder y el pensamiento del eterno retorno de lo mismo. Ya que esta cuestión sobrepasa ampliamente el marco de este artículo, nos permitimos enviar a nuestros estudios anteriores: «La nuova concezione del mondo’: volontà di potenza, pluralità di forze, eterno ritorno dell'identico", en S. Busellato (coord.), Nietzsche dal Brasile. Contributi alla ricerca contemporanea, Pisa: ETS, 2014, pp. 21-40; «L'éternel retour du même: thèse cosmologique ou impératif éthique?»: Nietzsche-Studien 25 (1996), 42-63. 
cepto de voluntad de poder aparece siempre relacionado con la noción de valor. Mucho más, está asociado de una manera u otra al proyecto de transvaloración de los valores.

El pensamiento del eterno retorno, a su vez, está sugerido en particular en tres secciones de la segunda parte del libro. En la sección titulada «De los grandes acontecimientos», los discípulos de Zaratustra relatan una escena que habían presenciado. En un momento dado, han visto a un hombre acercarse a ellos por el aire, anunciando que el tiempo había llegado; han reconocido que este hombre era $\mathrm{Za}$ ratustra. Al final de su relato, el personaje central se pregunta sobre el sentido que todo esto puede tener: «Por qué gritó el fantasma: iYa es tiempo! iYa ha llegado la hora! ¿De qué - ha llegado la hora?’» ${ }^{34}$. En la sección «De la redención», después de haber escuchado el discurso que Zaratustra hace a sus discípulos, un jorobado habla con él desafiándolo: «Mas ¿́por qué Zaratustra habla a sus discípulos de manera distinta - que a sí mismo?»35. En la sección titulada «La más silenciosa de todas las horas», algo sin voz habla a Zaratustra, instándolo a anunciar el eterno retorno. Y él mismo reconoce que no ha dicho todo a sus discípulos: «iAy, amigos míos! iYo tendría aún algo que deciros, yo tendría aún algo que daros! ¿Por qué no lo doy?»36. Lo que más nos importa en este momento de nuestra indagación es señalar que, entre el momento en el que Zaratustra deja de nuevo la soledad de su caverna y de su montaña para encontrarse con sus discípulos en las islas afortunadas, y el momento en el que se dispone una vez más a abandonarlos, se da cuenta progresivamente de su tarea. Será fundamental anunciar su «pensamiento abismal». El desarrollo de esta parte del libro es tal que, de anunciador del superhombre, Zaratustra se prepara para convertirse en el maestro del eterno retorno.

La tercera parte de Así habló Zaratustra se inicia con una sección en la que el personaje central afirma que él admite su destino, sin explicar sin embargo en qué consistiría. Inmediatamente después hace el relato de su lucha contra el espíritu de la pesadez, aclarando la actitud que ha adoptado frente a su adversario y el asunto sobre el que han discutido y relata después la visión que él ha tenido. Si el tema de la disputa de Zaratustra con el espíritu de la pesadez evoca el pensamiento del eterno retorno, la visión que él cuenta hace alusión de la noción de superhombre. El hecho es que esta visión se presenta como un enigma ${ }^{37}$, que solo será descifrado más adelante. A pesar de que ya ha evocado el pensamiento del eterno retorno en su combate con su enemigo más grande, Zaratustra muestra en la sección siguiente que le falta siempre el coraje para anunciar su "pensamiento abismal». Pasando revista de ciertos episodios de su trayectoria, se acuerda particularmente de los momentos en los que todo lo que le rodeaba le recordaba que el tiempo había llegado pero él no era capaz de escuchar su pensamiento. Si de

34. Así habló Zaratustra II, «De los grandes acontecimientos», KSA IV 171.

35. Así habló Zaratustra II, «De la redención», KSA IV 182.

36. Así habló Zaratustra II, «La más silenciosa de todas las horas», KSA IV 190.

37. Esto explica el título escogido para esta sección. A diferencia de lo que podríamos suponer a primera vista, no se trata de una visión y de un enigma, sino de una sola y única cosa. 
ahora en adelante logra llevarlo, todavía no puede incorporarlo. En este sentido dice: «Todavía no me he atrevido nunca a llamarte arriba: ya es bastante fuerte para la última arrogancia y petulancia del león» ${ }^{38}$.

A partir de este momento, las secciones que siguen aportan varias aclaraciones sobre puntos centrales de la filosofía de Nietzsche, sea arrojando luz sobre ideas que ya han sido introducidas en el libro sea presentando algunas nuevas. Zaratustra comienza afirmando que finalmente él se ha convertido en el que bendice. Después de eso, retomando ideas presentes en el Prólogo ${ }^{39}$, hace un discurso contra el hombre pequeño y presentándose como «el ateo», critica particularmente a los «maestros de resignación». Se dirige entonces al invierno y lo coge como cómplice, afirmando que se ha inventado un largo y luminoso silencio para escaparse de la compasión de la mayoría. En la puerta de una gran ciudad, se encuentra con un loco, llamado por el pueblo «el mono de Zaratustra»; quitándole la palabra, Zaratustra le hace ver que no basta con repetir de manera mecánica sus discursos sino que hay que incorporarlos. Todavía en la ciudad, usa como blanco de ataque a «los apóstatas», quienes, una vez convertidos en devotos, discuten sobre la creencia en Dios. De vuelta a su montaña, Zaratustra se reúne con la soledad; examinando las diferencias que existen entre estar solo en su caverna y sentirse abandonado entre los hombres, comprende que él no es más que un medio a través del que se expresa el devenir. Volviendo a la idea de que el mundo se le enfrenta, señala la relación entre bendecir y maldecir; ello le incita a revalorar el placer, el apetito por dominar y el egoísmo, otorgándoles un sentido nuevo. Recalcando que sus concepciones y su manera de proceder son muy diferentes de las del espíritu de la pesadez, Zaratustra señala que él le hace frente a través de la danza. Justo antes del anuncio del pensamiento del eterno retorno, retomando ideas ya expresadas a lo largo del libro, indica la dirección a tomar para llevar a buen término el proyecto de transvaloración de los valores ${ }^{40}$.

En la sección titulada «El convaleciente», apelando a su «pensamiento abismal», Zaratustra muestra la perspectiva que piensa adoptar y, hablando con sus animales, señala después los límites del lenguaje para expresar lo que él tiene que decir. Son el águila y la serpiente los que anunciarán el pensamiento del eterno retorno, pero es el mismo Zaratustra el que interpretará la visión que él ha tenido y descifrará el enigma que presenta.

Estrechamente relacionadas, la sección «De la visión y del enigma» y la titulada «El convaleciente» presentan el pensamiento del eterno retorno de lo mismo. A simple vista, podríamos suponer que constituyen un conjunto, de manera que si las leyéramos separadamente, plantearían problemas con respecto a la composición de la tercera parte del libro. Entre estas dos secciones, se encuentran otras diez, que, examinadas con mayor detalle, revelan sin embargo que Nietzsche tuvo la intención de poner en marcha un desarrollo conceptual absolutamente necesario para hacer posible el anuncio del pensamiento del eterno retorno. Después de haber aceptado

38. Así habló Zaratustra III, «De la bienaventuranza no querida», KSA IV 205.

39. Cf. Así habló Zaratustra I, «Prólogo», \5, KSA IV 19s., donde el personaje central toma como blanco de ataque al último hombre, el defensor de los valores establecidos.

40. Cf., respectivamente, Así habló Zaratustra III, «Antes de la salida del sol», «De la virtud empequeñecedora», «En el monte de los olivos», «Del pasar de largo», «De los apóstatas», «El retorno a casa», «De los tres males», «Del espíritu de la pesadez», «De las tablas viejas y nuevas». 
su destino, Zaratustra alude a su «pensamiento abismal» y relata su visión; ambos solo serán explicitadas en la sección titulada «El convaleciente». Consciente que él puede llevar el pensamiento del eterno retorno, pero no puede aún incorporarlo, Zaratustra introduce la noción de amor fati. En las secciones que siguen, toma sus distancias del hombre pequeño, vuelve a la cuestión de la comprensión de lo que tiene que decir, insiste en la importancia de la experiencia vivida, hace frente a las sombras de Dios, pretende ser el portavoz del mundo, procede a una revalorización de la manera de concebir los sentimientos humanos, presenta las armas de las que dispone para combatir el espíritu de la pesadez, señala la actitud a adoptar para llevar a cabo el proyecto de transvaloración de los valores. En las diez secciones que separan «De la visión y del enigma» $\mathrm{y}$ «El convaleciente», ya se trate de indicar los límites del lenguaje para expresar lo que él tiene que decir o de explicitar la manera de proceder que piensa adoptar, ya de reiterar sus blancos de ataque o de hacer ver la necesidad de destruir los valores establecidos con vistas a crear otros nuevos, Zaratustra no hace más que prepararse para el anuncio del pensamiento del eterno retorno. Todo va como si le fuese indispensable asegurarse del camino que había ya recorrido para estar preparado a abrazar su destino.

Podemos afirmar por lo tanto que la sección «De la visión y del enigma» y la titulada «El convaleciente» anuncian de manera diferente el pensamiento del eterno retorno. Para que Zaratustra consiga apoderarse de su «pensamiento abismal» le hará falta integrarlo como su experiencia vivida. Para que esté en condiciones de aceptar todas sus consecuencias, le será necesario poner en práctica el amor fati, convirtiéndose en el que bendice.

Es precisamente en la sección titulada «Antes de la salida del sol» de la tercera parte de Así habló Zaratustra donde Nietzsche introduce esta noción. Prodigando alabanzas al cielo, Zaratustra insiste allí en la idea de que él no abriga ninguna «voluntad eterna»; en el cielo, no hay lugar para ninguna clase de transcendencia. De este modo, destaca la inocencia del devenir, asociando a esta idea la noción de amor fati, como ya había hecho, por cierto, en la sección «De las tres transformaciones». Si en la primera parte del libro se limitaba a aludir a esta noción, ahora afirma haberla totalmente incorporado. «Me he convertido en uno que bendice y dice sí, y he luchado durante largo tiempo, y fui un luchador, a fin de tener un día las manos libres para bendecir». Y después del texto añade una indicación aún más esclarecedora: «Pero esta es mi bendición: estar yo sobre cada cosa como su cielo propio, como su techo redondo, su campana azul y su eterna seguridad: ibienaventurado quien así bendice!» ${ }^{41}$. No se trata pues de bendecir una situación precisa o un acontecimiento aislado; no se trata tampoco de decir sí a un sentimiento particular o a un comportamiento determinado. La noción de amor fati implica la aceptación sin restricción de lo que sucede; está por tanto íntimamente unida al pensamiento del eterno retorno.

No es una coincidencia que Nietzsche establezca el La gaya ciencia una estrecha relación entre Zaratustra, el pensamiento del eterno retorno y la noción de amor fati. Al comienzo del prólogo de Así habló Zaratustra, retoma ipsis litteris el último parágrafo del cuarto libro de La gaya ciencia. Si en este parágrafo (\$342) da a conocer a Zaratustra, en el anterior que lleva el título «El peso más grave»

41. Así habló Zaratustra III, «Antes de la salida del sol», KSA IV 209. 
$(\$ 341)$, expresa por primera vez en su obra publicada el pensamiento del eterno retorno de lo mismo ${ }^{42}$. Publicados inmediatamente antes de la elaboración de Así habló Zaratustra, estos dos parágrafos anticipan lo que será el personaje central ${ }^{43}$ y la concepción fundamental ${ }^{44}$ del libro. Es, además, el mismo Nietzsche quien nos proporciona estas claves de lectura. En Ecce Homo declara que La gaya ciencia «contiene cien indicios de la proximidad de algo incomparable; al final ella misma ofrece ya el comienzo del Zaratustra; en el penúltimo apartado del libro cuarto ofrece el pensamiento fundamental del Zaratustra ${ }^{45}$.

Es cierto que los dos últimos parágrafos de la cuarta parte de La gaya ciencia se encuentran íntimamente relacionados. Pero también es cierto que hay una estrecha relación entre ellos y el primer parágrafo de la misma parte del libro ${ }^{46}$. Nietzsche inicia esta parte de La gaya ciencia expresando un deseo. En el parágrafo titulado «Para el nuevo año» (\$2 276) afirma: «No quiero acusar, no quiero ni siquiera acusar a los acusadores. iQue mirar hacia otro lado sea mi única negación! $\mathrm{Y}$ en resumen y en total: iquiero ser alguna vez solo alguien que dice sí! ${ }^{47}$. No quiere presentarse como un iconoclasta o como un destructor; no quiere dedicarse a desenmascarar ideales o a demoler ídolos. Todo lo que desea es convertirse en alguien que afirma. Y Nietzsche concluye la cuarta parte del libro, presentando una concepción y un personaje ( $\$ 341$ y 342). Cuando introduce en el primer parágrafo la noción de amor fati, muestra la actitud que piensa adoptar de ahora en adelante. Cuando expresa el pensamiento del eterno retorno de lo mismo en el penúltimo parágrafo, da a entender la necesidad de incorporarlo. Cuando introduce a Zaratustra, permite suponer que es a él a quien corresponderá incorporar el pensamiento del eterno retorno y aceptar sus consecuencias, afirmando incondicionalmente lo que sucede.

Precisamente constatamos la elaboración y profundización de estas ideas en la tercera parte de Así habló Zaratustra. Es cierto que a la sección titulada «El convaleciente» le siguen otras tres. Sin embargo, no aportan desarrollos conceptuales precisos; se presentan sobre todo como momentos líricos. «Del gran anhelo», «La segunda canción del baile» y «Los siete sellos (o: la canción 'Sí y Amén'», como sus títulos nos llevan a suponer, constituyen pasajes en los que Zaratustra sigue el consejo que sus animales le habían dado. Inmediatamente después de su aceptación de las consecuencias del pensamiento del eterno retorno, el águila y

42. De hecho, la expresión «eterno retorno» aparece ya en la sección 285, KSA III 528, donde Nietzsche invita a su lector a renunciar a todo tipo de transcendencia, diciéndole: «te defiendes contra cualquier paz última, quieres el eterno retorno de guerra y paz».

43. En un poema de 1882, que inicialmente fue titulado «Portofino», Nietzsche se dedicó a describir la manera como concibió a Zaratustra (cf. el fragmento póstumo 3[3] del verano-otoño de 1882, KSA X 107s.). Algunos años más tarde, retomará este poema en las "Canciones del príncipe Vogelfrei», publicadas como un apéndice de la segunda edición de La gaya ciencia.

44. En uno de los primeros planes que Nietzsche elabora para la composición de un nuevo libro, concibe cuatro partes, en cuya última presenta la idea del eterno retorno. Cf. el fragmento póstumo 11[197] de primavera-otoño de 1881, KSA IX 520, donde podemos leer: «Cuarto libro. Contenido ditirámbico. 'Annulus aeternitatis'. Deseo de vivir todo de nuevo y eternamente».

45. Ecce Homo, «Así habló Zaratustra», $\mathbb{1}$, KSA VI 336.

46. A esta cuarta parte de la obra Nietzsche da el título de «Sanctus Januarius», en homenaje al año que acaba de comenzar.

47. La gaya ciencia $\$ 276$, KSA III 521. 
la serpiente le instan a cantar: «Pues mira, ioh Zaratustra! Para estas nuevas canciones se necesitan liras nuevas. Canta y cubre los ruidos con tus bramidos, oh Zaratustra, cura tu alma con nuevas canciones: ipara que puedas llevar tu grande destino, que no ha sido aún el destino de ningún hombre! ${ }^{48}$.

No obstante, analizando la tercera parte de Así habló Zaratustra, no podemos dejar de señalar que en la sección «De las tablas viejas y nuevas», que precede a la titulada «El convaleciente», el personaje central hace alusión de una manera muy concreta al pensamiento del eterno retorno. Vuelto por tercera vez a su montaña, Zaratustra es consciente de que tendrá que bajar al valle para encontrarse de nuevo con los hombres. Pero antes de su partida espera «los signos de que es mí hora, - a saber, el león riente con la bandada de palomas» ${ }^{49}$. Pero en la sección titulada «la más silenciosa de todas las horas», Nietzsche ha recurrido ya a la imagen de las palomas. En este pasaje, aludiendo al pensamiento del eterno retorno que su personaje está impulsado a anunciar, escribe: «Las palabras más silenciosas son las que traen la tempestad. Pensamientos que caminan con pies de paloma dirigen el mundo ${ }^{50}$.

En cuanto a la imagen del león que ríe, Nietzsche ya se sirve de ella en la sección titulada «De la bienaventuranza no querida». En este pasaje, pone en boca de Zaratustra la frase siguiente: «iAy, pensamiento abismal, que eres mi pensamiento! [...] Aún no era yo bastante fuerte para la última arrogancia y petulancia del león. Bastante terrible ha sido ya siempre para mí tu pesadez: imas alguna vez debo encontrar la fuerza y la voz del león, que te llame arriba! $\aleph^{51}$. De lo que acabamos de señalar, podemos concluir que mientras que las palomas remiten al eterno retorno de lo mismo, el león que rie se refiere a la actitud que Zaratustra deberá adoptar con respecto a su «pensamiento abismal», es decir, a la fuerza y audacia de la que debe dar prueba para extraer de ella las últimas consecuencias.

Es precisamente a la imagen del león riente con la bandada de palomas a la que Nietzsche recurrirá en todas las últimas páginas de la cuarta parte de Así habló Zaratustra ${ }^{52}$. En esta parte se ocupa de los hombres superiores, pero eso no le impide hacer alusión al final al pensamiento del eterno retorno. Si en la sección «De las tablas viejas y nuevas» de la tercera parte del libro la imagen del león riente con la bandada de palomas contribuía al desarrollo conceptual que conducía al anuncio del eterno retorno, ahora permite considerar la elaboración de una quinta parte. No es una casualidad que en la sección titulada «El signo» Nietzsche presente a su personaje disponiéndose a abandonar de nuevo su caverna y su montaña. Consciente de que se ha liberado de su compasión por el hombre superior, se da cuenta de que su hora ha llegado. Ya que el león riente con la bandada de palomas

48. Así habló Zaratustra III, «El convaleciente» \$2, KSA IV 275.

49. Así habló Zaratustra III, «De las tablas viejas y nuevas», $\mathbb{1}$, KSA IV 246.

50. Así habló Zaratustra II, «La más silenciosa de todas las horas», KSA IV 189. Cf. también la sección titulada «El convaleciente», donde los animales de Zaratustra, constatando su perturbación debido a las consecuencias causadas por el pensamiento del eterno retorno, le dicen: «iNo sigas hablando, convaleciente! [...] iSal fuera, a las rosas y a las abejas y a las bandadas de palomas!» (Así habló Zaratustra III, «El convaleciente», $\mathbb{2}$, KSA IV 275). Ocupándose de su personaje, Nietzsche retomará esta frase en Ecce Homo, «Prólogo», \$4, KSA VI 259.

51. Así habló Zaratustra III, «De la bienaventuranza no querida», KSA IV 205.

52. Cf. Así habló Zaratustra IV, «El signo», KSA IV 407. 
acudieron a él, él exclama: «Mi sufrimiento y mi compasión — iqué importan! Aspiro yo acaso a la felicidad iYo aspiro a mi obra! $\$^{53}$.

Habría sin embargo que recordar que la publicación de la cuarta parte de Así habló Zaratustra conoció una suerte muy particular. Dado que Schmeitzner, hasta entonces editor de sus obras, se negó de modo categórico a publicarla, Nietzsche se vio obligado en abril de 1885 a hacer una tirada de cuarenta ejemplares publicada por él mismo ${ }^{54}$. Era más que suficiente; esta cuarta parte solo quería enviarla a una decena de personas - y esto, de manera confidencial. Si bien es cierto que cuando la publica, Nietzsche tiene interés en llamarla «Cuarta y última parte», es cierto también que no hay que esperar mucho tiempo para que cambie de opinión con respecto al libro en su conjunto. Rechaza entonces las tres primeras partes que lo componen y tiene planeado concebir un nuevo Zaratustra a partir de la cuarta, contando con elaborar otras dos partes: la quinta y la sexta. Aunque no llegue a realizar este proyecto, el hecho es que hasta el otoño de 1888 manifiesta la intención de hacerlo. En 1891, Peter Gast publica esta cuarta parte, sin tener en cuenta lo que pensaría de ello Nietzsche, quien en ese momento, además, ya no era consciente de lo que ocurría a su alrededor. En 1893, teniendo en cuenta la reedición de Así habló Zaratustra, el editor Naumann reúne y publica por primera vez en un solo volumen las cuatro partes, sin tener en consideración la opinión del autor.

Los elementos reunidos hasta ahora nos permiten afirmar que la obra a la que Nietzsche dio su acuerdo, es decir un libro en tres partes, fue también rechazado por él y que por el contrario, la obra que no contó con su autorización, es decir, un libro en cuatro partes, es el que ha sido reconocido por la posteridad ${ }^{55}$. A partir de los análisis anteriores, de hecho podemos concluir que el desarrollo conceptual lo mismo que la acción dramática de la obra autorizada por Nietzsche, Así habló Zaratustra en tres partes, persiguen el objetivo de presentar la larga preparación del personaje central para incorporar el pensamiento del eterno retorno y para aceptar sus consecuencias, instando al lector a integrarse en este proceso.

Analicemos con más detenimiento la forma en que el pensamiento del eterno retorno es presentado en Así habló Zaratustra. En la sección titulada «De la visión y del enigma», después de haber dibujado el perfil del interlocutor con el que desea reunirse, Zaratustra relata su lucha contra su enemigo mortal, el espíritu de la pesadez. Ejerciendo una acción paralizante, su adversario siempre le detenía; con un gesto opresivo intentaba convencerlo de la imposibilidad de proseguir su

53. Así habló Zaratustra IV, «El signo», KSA IV 408.

54. Entre mediados del mes de marzo y mediados del mes de abril de 1885, Nietzsche lee con Peter Gast las pruebas de la cuarta parte, que aparece con el título de Also sprach Zarathustra. Ein Buch für Alle und Keinen. Vierter und letzter Theil, Leipzig: Constantin Georg Naumann, 1885.

55. Para un análisis más profundo de la elaboración conceptual y literaria que dio lugar a Así habló Zaratustra, remitimos a nuestro estudio "Ainsi parlait Zarathoustra: l'œuvre à la fois consacrée et reniée», en G. Campioni, L. P. Ciamarra y M. Segala (coords.), Goethe, Schopenhauer, Nietzsche. Saggi in memoria di Sandro Barbera, Pisa: ETS, 2011, pp. 481-498. 
camino. Es el valor el que ayudará a Zaratustra a desembarazarse del agobio que se adueñaba de él. Aludirá al valor para realizar lo que le corresponde.

El valor es el mejor matador: el valor mata incluso la compasión. Pero la compasión es el abismo más profundo: cuanto el hombre hunde su mirada en la vida, otro tanto la hunde en el sufrimiento. Pero el valor es el mejor matador, el valor que ataca: este mata la muerte misma, pues dice: ‘¿Era eso la vida? iBien! iOtra vez! ${ }^{56}$.

Con estas palabras, Zaratustra afirma la importancia del valor para combatir la compasión que impide acoger el sufrimiento, para superar el nihilismo que prohíbe aceptar la vida tal como es, para vencer la muerte que no es más que la eternidad prometida por la religión cristiana.

Una vez aclarada la actitud a adoptar, Zaratustra presenta por primera vez en el libro el pensamiento del eterno retorno de lo mismo. Empleando una imagen, la de un portón llamado «Instante», describe una situación en la que se juntan dos caminos que duran una eternidad: un camino que corre detrás del portón y otro que corre delante. Sin recurrir a ninguna argumentación y sin dar ninguna explicación, Zaratustra introduce la idea de que lo que ocurrirá en el camino que pasa delante del portón ha ocurrido ya en el camino de detrás, haciendo al mismo tiempo de manera retórica varias preguntas a su enemigo mortal:

Cada una de las cosas que pueden ocurrir, ¿no tendrá que haber ocurrido, haber sido hecha, haber transcurrido ya alguna vez? Y si todo ha existido ya: ¿qué piensas tú, enano, de este instante: No tendrá también este portón que - haber existido ya? Y no están todas las cosas anudadas con fuerza, de modo que este instante arrastra tras sí todas las cosas venideras? Por tanto — ¿̇incluso a sí mismo? ${ }^{57}$.

Retomando imágenes que se encuentran en el parágrafo 341 de La gaya cien$\mathrm{cia}^{58}$, Zaratustra insiste en los dos aspectos del pensamiento del eterno retorno que Nietzsche había ya presentado en su libro anterior.En La gaya ciencia, cuando expone su concepción del eterno retorno, Nietzsche señala estos dos aspectos que reaparecerán varias veces en sus textos: la repetición de los acontecimientos («cada dolor y cada placer y cada pensamiento y suspiro y todo lo indeciblemente pequeño y grande de tu vida tendrá que retornar a ti») y el movimiento circular en el que la misma serie de acontecimientos tiene lugar («y todo en la misma serie y la misma sucesión»). Si estos dos aspectos resultan esenciales en su pensamiento del eterno retorno de lo mismo, él pone de relieve aquí otro punto: «el peso más grave», que constituye el título mismo de este parágrafo, remite directamente a las consecuencias psicológicas que puede acarrear el pensamiento del eterno retorno. En definitiva ¿̇qué provocaría en nosotros?, ¿nos llenaría de alegría o nos lanzaría a la desesperación?, ¿̇cómo nos comportaríamos enfrente de este pensamiento?, ¿nos echaríamos al suelo y rechinarían los dientes? o

56. Así habló Zaratustra III, «De la visión y del enigma», $\mathbb{1}$, KSA IV 199.

57. Así habló Zaratustra III, «De la visión y del enigma» \$2, KSA IV 200.

58. Cf. Así habló Zaratustra III, «De la visión y del enigma» \$2, KSA IV 200, donde podemos leer: «Y esa araña que se arrastra con lentitud a la luz de la luna, y esa misma luz de la luna, y yo y tú, cuchicheando ambos junto a este portón, cuchicheando de cosas eternas - ¿no tenemos todos nosotros que haber existido ya?». 
¿acaso bendeciríamos como portador de una buena nueva a cualquier hombre que nos hablase de ello? Poco importa la actitud que lleguemos a adoptar, no nos liberaría del peso que de ahora en adelante recaería en nuestro actuar. Ni la aceptación ni el rechazo de este pensamiento podría evitar su impacto. Si nos dejásemos impregnar por él, seríamos perseguidos a cada instante por esta pregunta: «¿quieres esto otra vez e innumerables veces más?». Sin embargo, cuando Nietzsche presenta su pensamiento en La gaya ciencia, comienza precisamente con estas palabras: "Qué pasaría si un día o una noche...".

La formulación hipotética del pensamiento nietzscheano del eterno retorno de lo mismo en este parágrafo nos lleva a señalar su importancia en el contexto de la experiencia humana. No cabe duda de que este pensamiento no aparece como una tesis en La gaya ciencia, sino como una experimentación del pensamiento. No obstante, estamos obligados a recalcar que no nos referimos a que el carácter experimental de este pensamiento sea debido al hecho de que haya provocado un impacto en el mismo Nietzsche o que haya sentido la necesidad de incluirlo reflexivamente en su propia vida. Defendemos la idea de que, mucho más que un problema psicológico o una cuestión existencial, el experimentalismo debe ser considerado aquí como una opción filosófica. Experimentador en el más alto grado, Nietzsche no duda en invitar al lector a hacer experimentaciones, ya sea porque entiende que no somos más que experimentaciones ya sea porque juzga que no debemos exceptuarnos de hacer experimentaciones con nosotros mismos ${ }^{59}$. Cuando se ocupa de abordar un problema en sus múltiples aspectos, cuando se esmera en estudiar una cuestión desde varios puntos de vista de apreciación, cuando se dedica a reflexionar sobre una problemática adoptando diferentes perspectivas, se presenta como Versucher.

A la luz de dichas consideraciones debería analizarse la sección titulada «De la visión y del enigma» de la tercera parte de Así habló Zaratustra. En su lucha decisiva contra el espíritu de la pesadez, el personaje central le reprocha no ser capaz de llevar el pensamiento del eterno retorno. Incluso si su adversario viniese a sostener la idea de que todo vuelve sin cesar, no conseguiría soportarlo, no podría nunca experimentarlo. Por eso Zaratustra considera al espíritu de la pesadez como su mayor enemigo; por medio de su acción, arriesga ver su doctrina convertirse en un dogma incuestionable, su pensamiento convertirse en verdad definitiva, su experiencia vivida transformarse en imperativo categórico ${ }^{60}$. Así pues, Zaratustra hace hincapié en otro punto: el impacto que podría provocar su «pensamiento abismal». Y, en esta etapa de su camino, es muy consciente de las dificultades que él mismo debe superar para llegar a aceptarlo ${ }^{61}$.

Para intentar de entender lo que paraliza a Zaratustra, tratamos de interpretar «la visión del más solitario de los hombres» ${ }^{62}$ y de descifrar su enigma. Después de

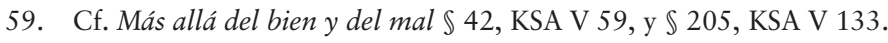

60. En Así habló Zaratustra III, «Del espíritu de la pesadez» $\$ 2$, KSA IV 245, el personaje central afirma: «Por muchos caminos diferentes y de múltiples modos llegué yo a mi verdad [...]. Un ensayar y un preguntar fue todo mi caminar».

61. Cf. Así habló Zaratustra III, «De la visión y del enigma» \$2, KSA IV 200s., donde el personaje central manifiesta su estado de ánimo de la manera siguiente: «Así dije, con voz cada vez más queda: pues tenía miedo de mis propios pensamientos y del trasfondo de ellos».

62. Es la expresión que Nietzsche había considerado como un título posible de esta sección. 
haber terminado el relato de su combate contra el espíritu de la pesadez, Zaratustra cuenta lo que vio. Presenció una escena en la que un joven pastor se retorcía con una serpiente negra colgándole de la boca. Afectado por la repugnancia y el espanto que se reflejan en su cara, intenta arrancar la serpiente de su garganta. Sin lograr hacerlo, grita al pastor que muerda su cabeza y la escupa lejos. Zaratustra insta entonces a sus interlocutores a descifrar su enigma, que consiste precisamente en la visión que acaba de relatar, diciéndoles: «Pues fue una visión y una previsión: - ¿qué vi yo entonces en símbolo? ¿Y quién es el que algún día tiene que venir aún?» ${ }^{63}$. No es a los interlocutores de Zaratustra a quienes corresponde interpretar «la visión del más solitario de los hombres»; incluso si fuesen capaces, no podrían hacerlo. Finalmente, la visión es ante todo una previsión; la gran transformación que anuncia deberá aún producirse.

Para concluir su relato, Zaratustra cuanta a sus interlocutores que, siguiendo su consejo, el pastor mordió la cabeza de la serpiente y a escupió bien lejos. Y añade: «Ya no pastor, ya no hombre, - iun transfigurado, iluminado que reía! ¡Nunca antes en la tierra había reído hombre alguno como él rio! [...] Mi anhelo de esa risa me devora: ioh, cómo soporto el vivir aún! iY cómo soportaría el morir ahora! ${ }^{64}$. En estos momentos de su camino, Zaratustra conoce muy bien su tarea; él es el anunciador del superhombre y está dispuesto a apoyar la transvaloración de todos los valores. iPero esto no basta! No es, sin embargo, en esta sección donde su gran transformación tendrá lugar. Preparada aquí, se cumplirá más adelante y, finalmente, su enigma será descifrado.

En la sección titulada «El convaleciente», Nietzsche insiste en la idea del eterno retorno. Y emplea la misma estrategia que había aplicado en la sección «De la visión y del enigma». Comienza indicando la perspectiva que él piensa adoptar y señala después lo que tiene que anunciar. Intentando despertar su «pensamiento abismal», Zaratustra se esmera en el momento de su evocación ${ }^{65}$ en encontrar las palabras para decir lo que en él no puede permanecer mudo. En este contexto él se presenta: «iTe llama Zaratustra, el ateo! ${ }^{66}$ Yo Zaratustra, el abogado de la vida, el abogado del sufrimiento, el abogado del círculo ${ }^{67}$ - ite llamo a ti el más abismal de mis pensamientos!»68.

Teniendo conocimiento de la muerte de Dios, Zaratustra, «el ateo», elimina el suelo mismo en el que los valores habían sido creados. Concluye así la travesía del nihilismo, que constituye una etapa imprescindible para llevar a cabo el proyecto de transvaloración de todos los valores. Manifestándose a favor de la vida, del sufrimiento y del círculo, Zaratustra, «el abogado de la vida, el abogado del sufrimiento, el abogado del círculo», pone de manifiesto la estrecha relación

63. Así habló Zaratustra III, «De la visión y del enigma» \$2, KSA IV 196.

64. Así habló Zaratustra III, «De la visión y del enigma» \$2, KSA IV 202.

65. «La evocación» fue uno de los títulos que Nietzsche había pensado para esta sección, que está compuesta por dos subsecciones. «La evocación» podría muy bien titular la primera subsección $\mathrm{y}$ «El convaleciente» la segunda.

66. La expresión aparece también en Así habló Zaratustra III, «De la virtud empequeñecedora», KSA IV 215, y en Así habló Zaratustra IV, «Jubilado», KSA IV 323.

67. Una parte de esta expresión ya se encuentra en la sección titulada «El adivino» de la segunda parte del libro, KSA IV 175; entonces un discípulo de Zaratustra se dirige a él diciéndole: «iTú no te hundirás en el ocaso, tú, abogado de la vida!».

68. Así habló Zaratustra III, «El convaleciente» $\mathbb{S} 1$, KSA IV 271. 
entre la vida concebida como la voluntad de poder, el sufrimiento considerado como una parte integrante de la existencia y el círculo entendido como la infinita repetición de todas las cosas. Cuando interpela al pensamiento del eterno retorno, sabe que es él el que tiene conocimiento de la muerte de Dios, el que acoge sin restricciones el sufrimiento, el que afirma que todo vuelve sin cesar. Ya que son nociones interdependientes, la vida, el sufrimiento y el círculo indican una sola y única dirección a seguir. En los atributos a los que Zaratustra recurre para presentarse, podemos señalar los temas centrales de la última filosofía de Nietzsche: la superación del nihilismo, el proyecto de la transvaloración de todos los valores, el concepto de voluntad de poder, el pensamiento del eterno retorno de lo mismo.

Después de haber aclarado la perspectiva a seguir, Zaratustra anuncia su «pensamiento abismal». En realidad, no es él quien lo hace, son sus animales. Dirigiéndose a Zaratustra, en una primera formulación, el águila y la serpiente le dicen: «Pues tus animales saben bien, oh Zaratustra, quién eres tú y quien tienes que llegar a ser: tú eres el maestro del eterno retorno, - iese es tu destino! El que tengas que ser el primero en enseñar esta doctrina, - icómo no iba a ser ese gran destino también tu máximo peligro y tu máxima enfermedad!» ${ }^{69}$. Sin duda, no es la infinita repetición de su propia existencia lo que teme Zaratustra. Ni tampoco teme el eterno retorno de una vida de penas y tribulaciones. A fin de cuentas, es muy consciente que el dolor no constituye una objeción a la existencia, que el sufrimiento es una parte integrante de la vida. Lo que le atemoriza es que vuelva el hombre pequeño. Ante esta idea, asqueado, siente náuseas.

Los análisis anteriores permiten destacar dos resultados. Mientras que en $\mathrm{La}$ gaya ciencia Nietzsche presenta su pensamiento del eterno retorno de lo mismo como un desafío existencial a su lector, en Así habló Zaratustra lo presenta como una prueba que el personaje central del libro debe afrontar. Pero si en las dos obras se encuentran los aspectos esenciales de su pensamiento del eterno retorno de lo mismo, la repetición de los acontecimientos y el movimiento circular en el que la misma serie de acontecimientos tiene lugar, el punto en el que Nietzsche hace hincapié se refiere a las consecuencias psicológicas que puede provocar su «pensamiento abismal».

Precisamente en este punto insistirá firmemente en la sección «El convaleciente». Dándose cuenta de la aproximación de su «pensamiento abismal», Zaratustra se deja apoderar por la náusea y se desploma al suelo. Cuando vuelve en sí, permanece en un estado de postración rodeado por el águila y la serpiente que esperan su recuperación. Una vez transcurridos siete días, volviendo de sus tribulaciones, se reúne con sus animales. Basándose en una manera de proceder recurrente, Zaratustra señala los límites del lenguaje antes de expresar lo que tiene que decir. Cuando quiere reiterar la importancia de su enseñanza, insiste siempre en la inadecuación de los medios de expresión de los que dispone ${ }^{70}$.

69. Así habló Zaratustra III, «El convaleciente» \$2, KSA IV 275s.

70. Cf. Así habló Zaratustra III, «El convaleciente» \$2, KSA IV 272. En este momento Zaratustra dice a sus animales: «Qué agradable es que existan palabras y sonidos: palabras y sonidos ino son acaso arco iris y puentes ilusorios tendidos entre lo eternamente separado?». Cuando se trata de expresar sus propias concepciones, Nietzsche pone a plena luz su deseo de encontrar una forma de expresión que no se limite a representar el mundo. Sobre esta problemática, remitimos a nuestro 
Es entonces cuando el propio Zaratustra interpreta su visión y descifra su enigma. Confía su cansancio a sus animales: la serpiente negra se había deslizado en su garganta y lo estrangulaba, pero él mordió su cabeza y la escupió muy lejos. Y les dice: «Mas ahora yo estoy aquí tendido, fatigado aún de ese morder y escupir lejos, enfermo todavía de la propia redención ${ }^{71}$. Revela a sus animales que él mismo era el pastor, que había sido objeto de su relato en la sección titulada «De la visión y del enigma»; les revela que la serpiente negra no era más que el desprecio que sentía por el hombre pequeño, la repugnancia que experimentaba por el que se deja apoderar del hastío más grande. Como él mismo les dice: «El gran hastío del hombre - él era el que me estrangulaba y el que se me había deslizado en la garganta: y lo que el adivino había profetizado: 'Todo es igual, nada merece la pena, el saber estrangula'» ${ }^{72}$.

Personaje de suma importancia, el adivino aparece en la segunda parte del libro. En el sentido que la interpretación cristiana del mundo había conferido a la existencia humana, el adivino viene a sustituir a la más completa ausencia de sentido; el ideal ascético es reemplazado por el «nihilismo suicida ${ }^{73}$. Predicando una nueva doctrina, difundiendo una nueva creencia, el veneno que él esparce alcanza a todos los dominios. Lo expresa de la manera siguiente: «Y vi venir una gran tristeza sobre los hombres. Los mejores se cansaron de sus obras. Una doctrina se difundió, y junto a ella corría una fe: 'iTodo está vacío, todo es idéntico, todo fue!'» ${ }^{74}$. A diferencia de Zaratustra, quien, guiado por la abundancia y el exceso, desciende hacia el valle para compartir su sabiduría, el adivino propaga la esterilidad. A diferencia del quien abandona su montaña para aportar la luz a los hombres, preconiza la gran fatiga. Mientras que Zaratustra quiere sumergirse en las profundidades para volver más fuerte ${ }^{75}$, el adivino desea dejarse devorar por las tinieblas. Ejerciendo una acción paralizante, preconiza la muerte en vida. Lograr hacer la travesía de este nihilismo implica aceptar la vida tal como es, incluyendo todo lo que ella contiene de abominable e infame. Este es el gran desafío que corresponderá a Zaratustra afrontar.

En la sección «El convaleciente», es el valor el que hace posible a Zaratustra cortar de una vez por todas la cabeza de la serpiente; es el valor el que le permite romper definitivamente con el «nihilismo suicida». En su condición de convaleciente, Zaratustra conoce ahora su redención ${ }^{76}$ : consiste en querer que todo vuelva de nuevo y otra vez innumerables veces, incluido el hombre pequeño; en pocas

estudio «Le problème du langage chez Nietzsche. La critique en tant que création»: Revue de métaphysique et de morale 2 (abril de 2012), 225-245.

71. Así habló Zaratustra III, «El convaleciente» \$2, KSA IV 273.

72. Así habló Zaratustra III, «El convaleciente» \$2, KSA IV 274.

73. Cf. La genealogía de la moral, «Tratado tercero», $\mathbb{S} 28$, KSA V 411.

74. Así habló Zaratustra II, «El adivino», KSA IV 172. Su discurso es retomado en la sección «De las tablas viejas y nuevas», $\mathbb{S} 16$, de la tercera parte del libro, KSA IV 257 , y en la sección «El saludo", de la cuarta, KSA 4.349.

75. Cf. Así habló Zaratustra I, «Del árbol de la montaña», KSA IV 51, donde podemos leer: «Al hombre le ocurre lo mismo que al árbol. Cuanto más quiere elevarse hacia la altura y hacia la luz, tanto más fuertemente tiende sus raíces hacia la tierra, hacia abajo, hacia lo oscuro, lo profundo».

76. En la sección titulada «De la redención» en la segunda parte del libro, KSA IV 179, Zaratustra aclara lo que él entiende por esta palabra: «Redimir a los que han pasado, y transformar todo 'fue' en un 'así lo quise' — isolo eso sería para mí redención!”. 
palabras, consiste en extraer las últimas consecuencias del pensamiento del eterno retorno. Por ello está preparado para asumir su «pensamiento abismal». Sus animales, el águila y la serpiente, se encargan entonces de anunciarlo: «Mira, nosotros sabemos lo que tú enseñas: que todas las cosas retornan eternamente, y nosotros mismos con ellas, y que nosotros hemos existido ya infinitas veces, $\mathrm{y}$ todas las cosas con nosotros» ${ }^{77}$.

Esta cita atrae nuestra atención sobre un aspecto del pensamiento nietzscheano del eterno retorno: la repetición de todos los acontecimientos. En los textos que hemos analizado hasta ahora, ya sean pasajes de Así habló Zaratustra o del parágrafo 341 de La gaya ciencia, este aspecto vuelve siempre. Nietzsche insiste en la idea del eterno retorno de lo mismo. Aparece con toda claridad en la sección titulada «El convaleciente». Los animales ponen en su boca las siguientes palabras:

Y si tú quisieras morir ahora, oh Zaratustra: mira también sabemos cómo te hablarías entonces a ti mismo [...]. Vendré otra vez, con este sol, con esta tierra, con este águila, con esta serpiente - no a una vida nueva o a una vida mejor o a una vida semejante: - vendré eternamente de nuevo a esta misma e idéntica vida, en lo más grande y también en lo más pequeño, para enseñar de nuevo el eterno retorno de todas las $\operatorname{cosas}^{78}$.

Lo que se repite, esto es lo que sucede: y no lo que podría eventualmente tener lugar. Son los acontecimientos reales los que vuelven: y no los acontecimientos lógicamente posibles. Más aún: lo que se repite, es la serie entera de acontecimientos: y no un acontecimiento aislado. Es «el gran año del devenir» el que vuelve: y no un periodo histórico determinado. No se trata, pues, de la repetición de arquetipos o de modelos. Tampoco se trata del retorno de acontecimientos similares o de simulacros de estos. Tajante, el pensamiento nietzscheano afirma que este momento que estamos viviendo ya ha sucedido y sucederá de nuevo un infinito número de veces exactamente de la misma manera como se produce ahora.

Zaratustra no se acuerda de haber sido el maestro del eterno retorno - él no podría incluso acordarse; son sus animales quienes se lo advierten. La revelación no le llega como una reminiscencia o una sensación de algo visto antes; es nueva, inesperada, incluso sorprendente. Para que el pensamiento del eterno retorno de lo mismo tenga un sentido, Zaratustra debe admitir que él ya lo ha olvidado un infinito número de veces, que ha sido atrapado por él en las etapas anteriores - y que de nuevo lo será en las etapas posteriores. Esta idea está sugerida en un fragmento póstumo del otoño de 1883, cuando Nietzsche estaba elaborando la tercera parte de Así habló Zaratustra. Ahí podemos leer: «Todo pasa — todo retorna - y el mismo pasar retorna. Este 'ahora' ha ocurrido ya - infinitas veces ha ocurrido

77. Así habló Zaratustra III, «El convaleciente» \$2, KSA IV 276.

78. Ibid.. 
ya. Esta doctrina no ha sido enseñada nunca antes. ¿Cómo? Ella ha sido enseñada infinitas veces. Zaratustra la ha enseñado infinitas veces» ${ }^{79}$.

Al pasar de una serie de acontecimientos a otra, no podemos contar con una evolución o un progreso, no podemos suponer alteraciones o cambios, no podemos ni siquiera esperar una continuidad. Nada se mantiene - menos aún la memoria o la consciencia. Debido a su origen biológico, la consciencia no es más que «un medio de la comunicabilidad», «un órgano de dirección ${ }^{80}$. Resultado de la relación del organismo con el mundo exterior, que implica acciones y reacciones de una parte y de la otra, no constituye - como la mayoría de los filósofos han supuesto- el rasgo distintivo entre el hombre y el animal. Luchando contra lo que les rodea, los seres vivos - tanto los hombres como los animales- se proveen de órganos que les hacen la supervivencia más fácil; la consciencia no es más que uno de ellos. Teniendo en cuenta su procedencia gregaria, la memoria, a la vez, no es más que «un activo no-querer-volver-a-liberarse», «un seguir y seguir queriendo lo querido una vez ${ }^{81}$. Esta no se corresponde con una imposibilidad pasiva de olvidar el pasado, de deshacerse de los recuerdos. Vinculada a los orígenes de la responsabilidad, asegura la cadena que une la voluntad al acto, que garantiza que el individuo sea capaz de prometer. Temporales, incluso efímeras, la memoria y la consciencia surgen en un momento determinado del ciclo cósmico; duran un cierto tiempo y desaparecen.

El eterno retorno se presenta no en los límites estrechos de la historia humana sino en la infinitud del tiempo. Si la memoria busca preservar las experiencias de una vida, la historia, esta memoria milenaria y colectiva, debería ser depositaria de las experiencias de la humanidad. Considerada como una ciencia, supondría la inteligibilidad de los acontecimientos; tomada como un dominio específico del saber, intentaría construir un mundo estable y conocido. Pero comparada con los ciclos cósmicos, ¿̇qué podría representar? Para responder a esta cuestión, nada mejor que dar la palabra una vez más a los animales de Zaratustra. Son ellos quienes le recuerdan su enseñanza, diciéndole: «Tú enseñas que hay un gran año del devenir, un monstruo de gran año: una y otra vez tiene este que darse la vuelta, lo mismo que un reloj de arena, para volver a transcurrir y a vaciarse: - de modo que todos estos años son idénticos a sí mismos, en lo más grande y también en lo más pequeño» ${ }^{82}$. Por eso no dudamos en afirmar que el pensamiento nietzscheano del eterno retorno de lo mismo tiene un carácter suprahistórico.

Formulando su «pensamiento abismal», Nietzsche se enfrenta a las filosofías que suponen una teleología objetiva rigiendo la existencia, a las teorías científicas

79. Fragmento póstumo 18[14], otoño de 1883, KSA X 570. Esta idea es retomada prácticamente en los mismos términos en la sección «El convaleciente» $\$ 2$, KSA IV 272s., en la que los animales de Zaratustra le dicen: «todas las cosas mismas bailan para quienes piensan como nosotros: vienen y tienden la mano, y ríen, y huyen, y vuelven. Todo va, todo vuelve; eternamente rueda la rueda del ser. Todo muere, todo vuelve a florecer, eternamente corre el año del ser. Todo se rompe, todo se recompone; eternamente la misma casa del ser se construye a sí misma. Todo se despide, todo vuelve a saludarse; eternamente permanece fiel a sí el anillo del ser».

80. Cf. Fragmento póstumo (372) 11[145], noviembre de 1887-marzo de 1888, KSA XIII 68.

81. La genealogía de la moral, «Tratado segundo», \$1, KSA V 292.

82. Así habló Zaratustra III, «El convaleciente» \$2, KSA IV 276. 
que asumen un estado final del mundo, a las religiones que prometen futuras recompensas y castigos. Rechaza la metafísica y el mundo suprasensible, el mecanismo y la entropía, el cristianismo y la vida después de la muerte. Estableciendo el pensamiento del eterno retorno de lo mismo, insiste en la necesidad de la supresión de los dualismos. Esencia versus apariencia, inmutabilidad versus transformación, eternidad versus cambio, en definitiva, todas las dicotomías deben caer al suelo. Postulando la homogeneidad de todos los acontecimientos, rechaza conceder al hombre un lugar privilegiado y, por el mismo movimiento, lo concibe como una parte integrante de todo lo que sucede.

A la luz de estas consideraciones sería necesario retomar por última vez la sección «El convaleciente» de la tercera parte de Así habló Zaratustra. Interpelando al personaje central, el águila y la serpiente ponen en su boca estas palabras: «'Ahora muero y desaparezco, dirías, y dentro de un instante seré nada. Las almas son tan mortales como los cuerpos. Pero el nudo de las causas, en el cual yo estoy entrelazado, retorna, — iél me creará de nuevo! Yo mismo formo parte de las causas del eterno retorno» ${ }^{83}$. Negando la oposición entre el ego y el fatum, Nietzsche sostiene que el ser humano comparte el destino de todas las cosas. Amar el destino no implica adoptar una actitud resignada o sumisa frente a él. Pero ello tampoco es razón suficiente para que se intente excluirlo sea lo que sea. Amar el destino es aceptar todo lo que hay de más terrible y doloroso, pero también de más alegre y exuberante en la vida; en pocas palabras, es afirmar de manera absoluta e incondicional todo lo que ocurre. Y no hay afirmación más incondicional de la existencia que la afirmación de que todo vuelve un incontable número de veces.

En Ecce Homo, Nietzsche afirma rotundamente que la «concepción fundamental de la obra» consiste en «el pensamiento del eterno retorno, esa fórmula suprema de afirmación a que puede llegarse en absoluto» ${ }^{84}$. Al final de nuestra investigación, estamos en condiciones de concluir que estas líneas no son fruto de un defecto inherente a toda visión retrospectiva; no se deben tampoco a objetivos estratégicos que persigue el filósofo en el momento en que las escribe. En este caso concreto, cuando él se manifiesta en 1888 sobre Así habló Zaratustra, este libro en tres partes elaborado entre 1883 y 1884, permanece fiel a lo que efectivamente realizó en el momento de su elaboración.

[Traducción de José Honorio Ruiz Universidad de Málaga]

83. Así habló Zaratustra III, «El convaleciente» \$2, KSA IV 276.

84. Ecce Homo, "Así habló Zaratustra», $\mathbb{S}$ 1, KSA VI 335. 
ESTUDIOS LIBRES 
